\title{
BONE HEALTH, MUSCLE STRENGTH AND LEAN MASS: RELATIONSHIPS AND EXERCISE RECOMMENDATIONS
}

SAÚDE ÓSSEA, FORÇA MUSCULARE MASSA MAGRA: RELAÇÕES ERECOMENDAÇÕES DE EXERCÍCIOS

SALUD ÓSEA, FUERZA MUSCULAR Y MASA MAGRA:RELACIONES Y RECOMENDACIONES DEEJERCICIOS

\begin{abstract}
Although muscle strength, lean mass and bone mineral content/density (BMC/BMD) are consistently reported as major outcomes of resistance training (RT), there is still no agreement on the RT regimen that is capable of achieving this result in men and women of different ages. This study describes the effects of RT on muscle strength, lean mass and bone mineralization, highlighting the relationships between them and analyzing the effectiveness of the RT protocol. Information searches were conducted in open access online academic libraries, using the BMC/BMD indices combined with muscle strength, body composition, and resistance exercises. The results showed changes in BMC/BMD in 72\% of the studies published in the last decade. Among these, $77 \%$ recommended loads $\geq 80 \% 1-\mathrm{RM}, 61 \%$ involved older individuals (> 60 years) and $61 \%$ had planning protocols of between 3 and 5 months ( 12-20 weeks). The results also highlight muscle strength as a promising index of variations in BMC/BMD, with a moderate to high level of association $\left(r^{2}>0.5\right)$, which are specific for men and women in relation to the body region with best responsiveness. Among the studies published in last decade, about $61 \%$ had protocols involving only RT, and of these, $82 \%$ observed combined changes in BMC/BMD, body composition and muscle strength. This review therefore concludes that RT is important for improving muscle strength, increasing lean mass (whole-body and regional) and preventing risk factors that could impair the mineral integrity of the bone tissue, in individuals of all ages and sexes. Level of Evidence l; Systematic review of Level I RCTs (and study results were homogenous).
\end{abstract}

Keywords: Bone density; Exercise; Body composition; Young adult; Aged; Sex factors.

\section{RESUMO}

Apesar de a força muscular, a massa magra e o conteúdo/densidade mineral óssea (BMC/BMD) serem sistematicamente relatados como os principais resultados do treinamento resistido (TR), ainda não há acordo sobre o protocolo de TR capaz de promover esse resultado em homens e mulheres de diferentes faixas etárias. O presente estudo descreve os efeitos do TR sobre força, massa magra e mineralização óssea, destacando as relações entre eles e analisando a eficiência do protocolo de TR. As pesquisas das informações foram feitas em bancos de dados acadêmicos de acesso aberto, usando os indexadores "BMC/BMD" combinados com força muscular, composição corporal e exercícios resistidos. Os resultados mostraram mudanças no BMC/BMD em 72\% dos estudos publicados no último decênio. Entre estes, $77 \%$ recomendaram cargas $\geq 80 \%$ DE 1 RM, 61\% envolveram idosos (> 60 anos) e 61\% tiveram protocolos de planejamento entre 3 e 5 meses ( 12 a 20 semanas). Os resultados também destacam a força muscular como um índice promissor de variações de BMC/BMD, com nível moderado a alto de associação $\left(r^{2}>0,5\right)$, que são específicos para homens e mulheres em relação à região corporal com melhor responsividade. Entre os estudos publicados no último decênio, cerca de $61 \%$ tinham protocolo que envolveu apenas TR e deles, 82\% observaram alterações conjuntas de BMC/BMD, composição corporal e força muscular. Portanto, esta revisão conclui que o TRé importante para melhorar a força muscular, aumentar a massa magra (regional e corporal) e prevenir fatores de risco que podem comprometer a integridade mineral do tecido ósseo, em qualquer faixa etária e de ambos os sexos. Nível de Evidência l; Revisão sistemática de ECRC (Estudos clínicos randomizados e controlados).

Descritores: Densidade óssea; Exercício; Composição corporal; Adulto jovem; Idoso; Fatores sexuais.

\section{RESUMEN}

A pesar de que la fuerza muscular, la masa magra y el contenido/densidad mineral ósea (CMO/DMO) se informan sistemáticamente como los principales resultados del entrenamiento resistido (ER), todavía no hay acuerdo sobre el protocolo de ER capaz de promover ese resultado en hombres y mujeres de diferentes grupos de edad. El presente estudio describe los efectos del ER sobre la fuerza muscular, masa magra y mineralización ósea, destacando las relaciones entre ellos y la eficiencia del protocolo de ER. La investigación de las informaciones fue hecha en bases de datos académicas de acceso abierto, usando los indexadores "BMC/BMD" combinados con fuerza muscular, composición corporal y ejercicios resistidos. Los resultados mostraron cambios en el CMO/DMO en 72\% de los estudios publicados en el último decenio. Entre estos, 77\% recomendaron cargas $\geq 80 \% 1$ RM, 61\% involucraron a persona mayores (> 60 años) y $61 \%$ tenían protocololos de planificación de entre 3 y 5 meses ( 12-20 semanas). 
Los resultados también destacan la fuerza como un índice prometedor de variaciones de CMO/DMO, con nivel moderado a alto de asociación $\left(r^{2}>0,5\right)$, que son específicos para hombres y mujeres en relación a región corporal con mejor respuesta. Entre los estudios publicados en el último decenio, alrededor de $61 \%$ tenían protocolo que involucra sólo ERy de ellos, el 82\% observaron alteraciones conjuntas de CMO/DMO, composición corporal y fuerza muscular. Por lo tanto, esta revisión concluye que el ER es importante para mejorar la fuerza muscular, aumentar la masa magra (regional y corporal) y prevenir factores de riesgo que pueden comprometer la integridad mineral del tejido óseo, en cualquier grupo de edad y de ambos sexos. Nivel de Evidencia l; Revisión sistemática de ECRC (Estudios clínicos randomizados y controlados).

Descriptores: Densidad ósea; Ejercicio; Composición corporal; Adulto joven; Anciano; Factores sexuales.

\section{INTRODUCTION}

Bone mineral content (BMC) is a component of body composition, structuring the fat-free mass (IGM) when associated with lean mass (musculature and viscera). ${ }^{1-3}$ Bone mineral density (BMD), in turn, reflects the integrity of the bone tissue, being an indication of the structural remodeling capacity and, therefore, an index of the risk of propensity to the pathologies and lesions associated with the tissue. ${ }^{1,4}$ At present, the loss of bone tissue integrity by the reduction of the mineral mass does not has been associated only with the aging process or hormonal disorders, but also with the reduction of fat mass (FM) and lean mass (LM), due to dietary interventions for body weight loss and sedentary lifestyle, respectively. ${ }^{1,5,6}$

In general terms, resistance or resistive types of physical exercise tends to induce BMD changes due to mechanical stress on the bones, evidencing the exercise potential in the maintenance of BMC/BMD with aging. ${ }^{5}$ The role of aerobic exercise at moderate intensity (ie: walking) is to induce BMC/BMD changes by increasing the gravitational load on the skeleton. ${ }^{7-9}$ However, the results show small effective changes and speculate that higher intensity exercises would bring greater benefits to prevention/treatment of disorders associated with BMD reduction, although there are no conclusive studies on the exercise intensity most suitable. ${ }^{7-10}$ In turn, resistance exercise has prescriptions that are effective for the regulation of BMD, which includes exercises with high loads: 12 to 15 RMs or $70-80 \% 1$ RM. ${ }^{11-14}$

Although the relationship between muscle strength and BMC/BMD has been evidenced, it is assumed that between young, active, or athletic individuals with intact bone health, increased strength does not play a decisive role to further increments in bone structures. This assumption is in line with the demonstration of the existence of a setpoint, in addition to which the mechanical stimulus does not result in gains in bone mass. This setpoint, in turn, is one of the main foundations of the "mechanostat" theory, ${ }^{15}$ which governs the Utah paradigm for skeletal physiology, relating mechanical stress to bone remodeling, within a limit of normality for mass/density, which has been used to justify the lack of cause and effect relationship between strength and/or MM associations to BMC/ BMD of adult individuals enrolled in regular sports training programs. ${ }^{16-18}$

Thus, although muscle strength and LM are considered as dominant mechanical stimuli, BMC/BMD are also related to other non-mechanical stimuli (metabolic or hormonal), which modulate both bone and muscle metabolism, or simply modulate responsiveness of bone tissue (BMC/BMD variations) to mechanical stress. ${ }^{16,19}$ Therefore, this systematic review aims to describe the fundamentals of the cause-effect relationship between the patterns of changes in LM and muscle strength with variations of $\mathrm{BMC} / \mathrm{BMD}$, sustaining the mechanical effect of resistance exercise as a modulating factor of the activation of the bone remodeling system, and able to adjust the balance for bone mass gain directly and independently of age, sex and bone health status

\section{METHODS}

\section{Sources of bibliographic survey}

The information was obtained from scientific health databases, such as the Athena and Parthenon systems (periodicals catalogs and the State and Federal Public Libraries network of the State of São Paulo), which include the Turnitin, Scielo, MEDLINE, Capes, SportDiscus, Scopus and DOAJ (Directory of Open Access Journals). After the Local Ethics Committee of the University approved this research (CAEE: 70076317.1.0000.5398), the bibliographic survey was perform following the procedures presented in Figure 1A, which are further detailed bellow:

a. Insertion of keywords: Bone Density, Bone mineral content, Bone remodeling and Bone metabolism.

b. Combination with terms of interest: Body composition, Lean mass, Fat mass, Muscle strength, Absortiometry (DXA), Young, Young adults, Adults, Elderly, Menopause, Osteoporosis, Aerobic training, Resistance exercise, Training high intensity; Impact exercises.

c. From the summaries found, the texts were included or excluded according to the criteria presented in Figure 1B and described as follows:

\section{Criteria for selection of bibliographic material}

Inclusion criteria were: (1) BMC/BMD as the main descriptor; and (2) age, gender, ethnicity, and physical training as secondary descriptors. In addition the texts should: (1) be available in its entirety, (2) associate at least three descriptors in the approach, (3) present the description of the training program, and (4) on BMC/BMD, body composition and muscle

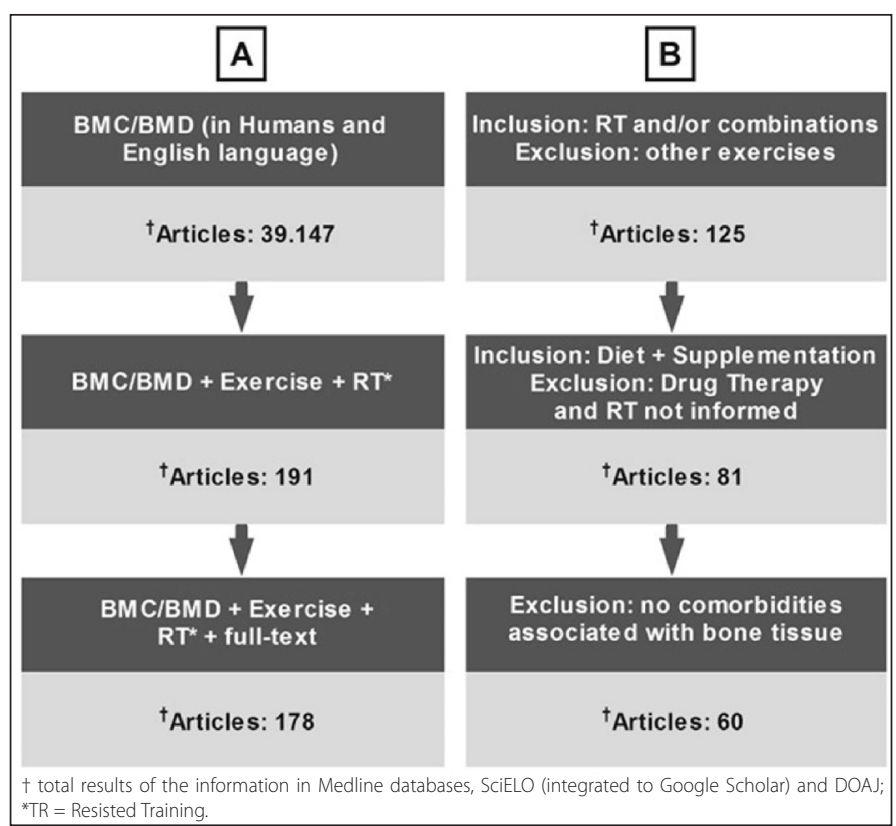

Figure 1. Procedure for data acquisition (Panel A) and selection criteria (inclusion/ exclusion) of the articles (Panel B). 
strength, in any combination including BMC/BMD. Also, approaches involving strategies of food control and supplementation was admit.

Were adopt as exclusion criterion: (1) texts that did not addressed the effect of resistance exercise, (2) animal research and engineering trials, (3) texts outside the Sports Science area, clinical pathology and rehabilitation, or individuals under drug therapy, and (4) texts without English version.

\section{RESULTS}

A total of 39,147 references indexed by the BMC/BMD descriptors were sampled. Of these, 178 references met eligibility for addressing BMC/BMD in a context of intervention with resistive exercise in the last decade (Figure 1A). From the inclusion/exclusion criteria, 60 references were analyzed, of which 30\% (18 studies) presented interventions with resistance training (RT), published in the last five (Table 1) or ten years (Table 2). Of these, 50\% has training planning between 3-5 months ( 12-20 weeks), and the others between 6 and 48 months. Regarding the characteristics of the population, 33\% of these studies involved women and 38\% involved a mixed population, and in 55\% of the studies the participants was $>60$ years old. Regarding the prescription of resistance exercise, $~ 78 \%$ used high intensity of load ( $\geq 80 \% 1 \mathrm{RM}$ and $\leq 8$ maximum repetitions). The changes of BMC/BMD were observe in 72\% of the 18 studies on Tables 1 and 2. In these studies, 77\% prescribed loads $\geq 80 \% 1 \mathrm{RM}, 61 \%$ involved elderly (> 60 years) and $61 \%$ planned intervention between 3-5 months $(\sim 12-20$ weeks). Only one study (5\%) reported the presence of blacks among participants. Among the studies highlighted in Tables 1 and 2, approximately $61 \%$ applied only RT, and of these $82 \%$ observed changes of BMD/BMC together with changes of body composition and muscle strength. Those studying RE combined with aerobic exercise amounted 16.7\%, of which $66.7 \%$ observed changes in BMD/BMC, body composition and muscle strength. Finally, the studies using RT combined with the impact exercise (jump and variations) are 22.2\%, from which 75\% showed improvements in BMD/BMC, body composition and muscle strength.

\section{DISCUSSION}

\section{Age, Sex and bone remodeling: fundamental theoretical interrelationships with body composition and exercise}

It has been observed that BMD reduction is positively associated with age, showing rates of $0.6 \%, 1.1 \%$ and $2.1 \%$ of loss, respectively, for the age groups between 60-69, $70-79$ and $\geq 80$ years. ${ }^{5}$ These changes often culminate with osteoporosis, but tend to be minimized by regular physical activity and maintenance of MG and LM patterns., ${ }^{5,36-38}$ When analyzing the association between aging, decline in physical activity, and BMC and LM reductions, Proctor et al..$^{6}$ observed that between 20 and 80 years of age there is a trend of reduction in physical activity between 34-38\% for women and men, while reduction in LM (18-17\%) and BMC (16-30\%).

In the study by Proctor et al. ${ }^{6}$ this decline was quantified. For these authors, BMC/BMD declines 30\% between 20 and 80 years in women, but only $16 \%$ in this same age range among men. The reduction in LM is $18 \%$ and $17 \%$, and physical activity is $34 \%$ and $38 \%$, respectively among women and men in the same age range described above. That is, men tend to maintain a more stable LM-BMC ratio in fat-free mass composition when compared to women, but the mobility and vitality of men are more susceptible to BMC/BMD and LM reductions, impacting maintenance of physical activity levels more than in women. ${ }^{37}$

However, among women, after the menarche and with the predominance of estrogen secretion on growth and sex hormones, there is a stabilization of bone mineralization and LM, concomitant with the accumulation of FM, which is in line with the observation that young women tend to maintain healthy BMC/BMD levels with the increase of $L M{ }^{39}$ Therefore, these authors conclude that the level of physical activity may be a potentially better factor than variations in sex hormones to explain the modulation of BMD in both regions exposed to body weight (i.e.: hip and spine), and those not exposed (i.e.: bone radio), since exercise is able to modify LM.

Table 1 - Resistance Training (RT) and bone mineral density response (BMD) intervention studies, over last 5 years.

\begin{tabular}{|c|c|c|c|c|}
\hline Study & Variables & RT Protocol & Participants & Results \\
\hline $\begin{array}{c}\text { Cunha } \\
\text { et al. }(2018)^{20}\end{array}$ & Whole-body BMD & $\begin{array}{l}\text { RT: } 1 \text { set vs. } 3 \text { sets, } 10-15 \mathrm{RM}^{*}, 1-2 \text { min. rest } \\
\text { between sets, } 3 \text { weekly sessions for } 12 \text { weeks. } \\
\text { Progression: } 2-5 \% \text { and } 5-10 \% \text { for } U L \text { and } L^{* *} \text {. }\end{array}$ & $\begin{array}{l}62 \text { Women (osteosarcopenic) } \\
68.0 \pm 4.3 \text { years }\end{array}$ & $\begin{array}{l}\text { None of the ST protocols } \\
\text { altered whole-body BMD. }\end{array}$ \\
\hline $\begin{array}{l}\text { Huovinen et } \\
\text { al. }(2016)^{21}\end{array}$ & $\begin{array}{l}\text { Hip, femoral neck e } \\
\text { trochanteric BMD }\end{array}$ & $\begin{array}{l}\text { RT: } 3 \text { sets, } 8-15 \text { repetitions, } 50-85 \% \\
\text { 1RM, } 3 \text { weekly sessions for } 16 \text { weeks }\end{array}$ & $\begin{array}{l}37 \text { Women between 68-78 } \\
\text { years (low strength fitness) }\end{array}$ & $\begin{array}{l}\text { Alteration of } 6 \% \text { hip BMD, } \\
\text { by the change } 10.7 \% \text { inter- } \\
\text { trochanteric BMD. }\end{array}$ \\
\hline $\begin{array}{c}\text { Watson } \\
\text { et al. }(2015)^{22} \\
\end{array}$ & $\begin{array}{l}\text { Whole-body, lumbar } \\
\text { and femoral neck BMD }\end{array}$ & \begin{tabular}{|c|} 
RT: 5 sets, 5 repetitions, $80-85 \%$ 1RM, 2 weekly \\
sessions for $\sim 32$ weeks + impact exercises.
\end{tabular} & $\begin{array}{c}28 \text { Womens }>60 \text { years (T-score } \\
<-1,0 \text { hip/vertebrae) }\end{array}$ & $\begin{array}{l}\text { Alteration of } 0.3 \% \text { and } 1.6 \% \text { BMD } \\
\text { femoral neck and hip in group ST. }\end{array}$ \\
\hline $\begin{array}{c}\text { Villareal } \\
\text { et al. }(2017)^{7} \\
\end{array}$ & $\begin{array}{l}\text { Whole-body, lumbar } \\
\text { e hip BMD }\end{array}$ & $\begin{array}{l}\text { RT in progression of } 1-3 \text { sets, } 65-85 \% \\
1 \text { RM, } 3 \text { weekly sessions for } 26 \text { weeks. }\end{array}$ & $\begin{array}{l}141 \text { (Men } \sim 35 \% \text {; and Women } \sim 65 \%)> \\
65 \text { years ( 4\% blacks e } \sim 31 \% \text { Hispanics) }\end{array}$ & Non-significant changes in BMD. \\
\hline $\begin{array}{l}\text { Beavers et al., } \\
(2017)^{23}\end{array}$ & $\begin{array}{l}\text { Lumbar, left hip, femoral } \\
\text { neck, and trochanter BMD }\end{array}$ & $\begin{array}{c}\text { RT: } 3 \text { sets, 70\% 1RM, } 10 \text { repetitions, } 3 \\
\text { weekly sessions for } \sim 20 \text { weeks. }\end{array}$ & $\begin{array}{l}123 \text { (Men 33\%; and Women } \sim 67 \% \text { ) 65-79 } \\
\text { years ( 81\% white), osteopenia in } \sim 53 \%\end{array}$ & $\begin{array}{l}\text { Alteration of hip and femoral } \\
\text { neck BMD in ST group + Diet. }\end{array}$ \\
\hline $\begin{array}{c}\text { Petersen } \\
\text { et al. }(2017)^{24}\end{array}$ & $\begin{array}{l}\text { Arms, legs, vertebrae } \\
\text { and pélvis BMD }\end{array}$ & $\begin{array}{l}\text { RT: } 1 \text { set, } 100 \text { repetitions (4-5 min. exercise), } \\
\text { 20\% 1RM, } 2 \text { weekly sessions for } 12 \text { week } \\
\quad+1 \text { session for another } 12 \text { weeks. }\end{array}$ & $\begin{array}{l}20 \text { (6 Men e } 14 \text { Women) } \\
\text { between } 28-63 \text { years }\end{array}$ & $\begin{array}{l}\text { Alteration of BMD: } 4 \% \text { arms, } 8 \% \\
\text { legs, } 6 \% \text { pelvis e } 4 \% \text { vertebrae. }\end{array}$ \\
\hline $\begin{array}{c}\text { Stunes } \\
\text { et al. }(2017)^{25}\end{array}$ & $\begin{array}{l}\text { Whole-body, lumbar, hip } \\
\text { and femoral neck BMD }\end{array}$ & $\begin{array}{l}\text { RT: } 2 \text { weekly sessions with 8-10 RM (rest: } \\
1 \text { min.) + } 1 \text { session 3-5 RM (rest: } 2 \text { min.) } \\
\text { ou 13-15 RM (rest: } 45 \text { s), for } 12 \text { weeks. }\end{array}$ & 35 Men > 60 years & $\begin{array}{l}\text { Alterations in lumbar and hip } \\
\text { BMD in the group without } \\
\text { supplementation of vitamins } C+E \text {. }\end{array}$ \\
\hline $\begin{array}{c}\text { Bolam } \\
\text { et al. }(2015)^{26}\end{array}$ & $\begin{array}{l}\text { Lumbar, hip and } \\
\text { femoral neck BMD }\end{array}$ & $\begin{array}{l}\text { RT: } 2 \text { sets, } 12 \text { repetitions with } 60 \% \text { 1RM, } \\
2 \text { weekly sessions }+2 \text { sessions of impact } \\
\text { exercises (different volumes) for } \sim 36 \text { weeks. }\end{array}$ & 42 Men $\geq 50$ years & $\begin{array}{l}\text { Non-significant BMD changes in } \\
\text { relation to the control group. }\end{array}$ \\
\hline $\begin{array}{c}\text { Hinton } \\
\text { et al. }(2015)^{27}\end{array}$ & $\begin{array}{l}\text { Whole-body, lumbar } \\
\text { and hip BMD }\end{array}$ & $\begin{array}{l}\text { RT: 6-week cycles, progressing every two } \\
\text { weeks: 3-5 sets, 3-10 repetitions, 50-90\% } \\
\text { 1RM, } 2 \text { weekly sessions, for } 12 \text { months. }\end{array}$ & 38 Men between $25-60$ years & $\begin{array}{l}\text { Alteration in whole-body } \\
(0.6 \%) \text {, lumbar (1.3\%) and hip } \\
(0.8 \%) \text { BMD in } 6 \text { months. }\end{array}$ \\
\hline $\begin{array}{c}\text { Cunha } \\
\text { et al. }(2015)^{28}\end{array}$ & $\begin{array}{l}\text { Whole-body, arms, } \\
\text { legs and trunk BMC }\end{array}$ & $\begin{array}{c}\text { RT: } 3 \text { sets, } 15 \text { repetitions with 60\% } \\
\text { 1RM, } 3 \text { weekly sessions for } 12 \text { weeks. } \\
\text { Load progression (70-80\% 1RM, 6-12 } \\
\text { repetitions), every } 4 \text { weeks. }\end{array}$ & 18 Boys aged $10-12$ years & $\begin{array}{l}\text { Changes in whole-body, arms, } \\
\text { legs and trunk BMC with greater } \\
\text { effect in the ST group }\end{array}$ \\
\hline \begin{tabular}{c|} 
Mosti \\
et al. $(2014)^{29}$ \\
\end{tabular} & Lumbar and hip BMD & $\begin{array}{l}\text { RT: } 4 \text { sets, 3-5 repetitions with } 85-90 \% 1 \mathrm{RM} \\
\text { (rest: } 2-3 \text { min.), } 3 \text { weekly sessions for } 12 \text { weeks. }\end{array}$ & 29 Women 18 - 27 years & $\begin{array}{l}\text { Alterations in lumbar and } \\
\text { hip BMD of } 2.2 \% \text { and } 1 \% \text {. }\end{array}$ \\
\hline
\end{tabular}


Table 2. Resistance training (RT) and bone mineral density response (BMD) intervention studies, over last 10 years.

\begin{tabular}{|c|c|c|c|c|}
\hline Study & Variables & RT Protocol & Participants & Results \\
\hline $\begin{array}{l}\text { Romero- } \\
\text { Arenas } \\
\text { et al. }(2013)^{30}\end{array}$ & Whole-body BMD & $\begin{array}{l}\text { RT: } 2 \text { weekly sessions, } 1-3 \text { sets (rest: } 3 \\
\text { min.), } 12,10 \text { and } 6 \text { maximal repetitions ( } ~ \\
\text { 50-75\% 6RM and } 85-90 \% \text { 1RM), } 2 \text { blocks } \\
\text { of } 3 \text { exercises (rest: } 5 \text { min pause), for } 12 \\
\text { weeks. Traditional and Circuit-trainning. }\end{array}$ & $\begin{array}{l}35 \text { Men and Women } \\
\text { 55-75 years }\end{array}$ & $\begin{array}{l}\text { Alteration of Whole-body BMD } \\
1.1 \% \text { and } 1.2 \% \text { for Traditional } \\
\text { ST and Circuit-training. }\end{array}$ \\
\hline $\begin{array}{l}\text { Bemben \& } \\
\text { Bemben } \\
(2011)^{31}\end{array}$ & $\begin{array}{l}\text { Whole-body, lumbar and hip BMD, } \\
\text { femoral neck and trochanter BMD }\end{array}$ & $\begin{array}{l}\text { RT: } 2 \text { and } 3 \text { weekly sessions, } 3 \text { sets, } 8 \\
\text { repetitions with } 80 \% 1 \mathrm{RM} \text { and } 3 \text { sets, } 16 \\
\text { repetitions with } 40 \% 1 \mathrm{RM} \text {, for } 40 \text { weeks. }\end{array}$ & $\begin{array}{l}45 \text { Men e } 79 \text { Women } \\
\text { betweens 55-74 years }\end{array}$ & $\begin{array}{l}\text { Alterations in lumbar BMD 1.2\% (2 } \\
\text { sessions 80\% 1RM) and trochanter } \\
\text { BMD 1.5\% (3 sessions 40\% 1RM) }\end{array}$ \\
\hline $\begin{array}{l}\text { Almstedt } \\
\text { et al. }(2011)^{32}\end{array}$ & Hip and lumbar BMD & $\begin{array}{l}\text { RT: } 3 \text { weekly sessions with 67-95\% 1RM } \\
\text { (multi-joint exercises) combined with 67-80\% } \\
\text { 1RM (supplementary exercises), for } 24 \text { weeks. }\end{array}$ & $\begin{array}{l}29 \text { Men and Women } \\
\text { between } 18-23 \text { years }\end{array}$ & $\begin{array}{l}\text { Alterations between } 2.7 \% \text { to } \\
\text { 7.7\% BMD in Men. In women, } \\
\text { BMD changed }-0.8 \text { to } 1.5 \% \text {. }\end{array}$ \\
\hline $\begin{array}{l}\text { Marques } \\
\text { et al. }(2011)^{4}\end{array}$ & $\begin{array}{l}\text { Hip, femoral neck, trochanter } \\
\text { and inter-trochanteric BMD }\end{array}$ & $\begin{array}{c}\text { RT: } 3 \text { weekly sessions, } 2 \text { sets with } 50-60 \% \text { 1RM } \\
\text { (10-15 repetitions), progressing after } 2 \text { weeks } \\
75-80 \% \text { 1RM (6-8 repetitions), for } 32 \text { weeks. }\end{array}$ & $\begin{array}{l}71 \text { Women between } \\
\text { 60-95 years }\end{array}$ & $\begin{array}{l}\text { Alterations of } 2.9 \% \text { and } 1.5 \% \text { BMD of } \\
\text { the trochanter and hip for the ST group. }\end{array}$ \\
\hline $\begin{array}{l}\text { Liang at al. } \\
\qquad(2011)^{33}\end{array}$ & $\begin{array}{c}\text { Whole-body, lumbar, hip, } \\
\text { femoral neck, trochanter, triangle } \\
\text { Ward arms and legs BMD }\end{array}$ & $\begin{array}{l}\text { RT: } 3 \text { weekly sessions, } 1-3 \text { sets, } 8-15 \text { repetitions, } \\
\text { 65-80\% } 1 \text { RM, for } \sim 48 \text { weeks ( } 12 \text { months). }\end{array}$ & $\begin{array}{l}51 \text { Women between } \\
\text { 20-35 years }\end{array}$ & $\begin{array}{l}\text { Non-significant changes in the } \\
\text { BMD sites of the ST group. }\end{array}$ \\
\hline $\begin{array}{l}\text { Vani et al. } \\
(2010)^{34}\end{array}$ & $\begin{array}{l}\text { Lumbar and right } \\
\text { femoral neck BMD }\end{array}$ & $\begin{array}{l}\text { RT: } 3 \text { weekly sessions, } 3-4 \text { series, } \\
\text { 6-20 maximum repetitions, linear or } \\
\text { wave progression, for } 28 \text { weeks. }\end{array}$ & $\begin{array}{l}30 \text { Women between } \\
\text { 35-44 years }\end{array}$ & $\begin{array}{l}\text { Non-significant changes in the } \\
\text { BMD sites of both ST groups. }\end{array}$ \\
\hline $\begin{array}{l}\text { Warren } \\
\text { et al. }(2008)^{35}\end{array}$ & $\begin{array}{l}\text { Lumbar, femoral neck, } \\
\text { and trochanter BMD }\end{array}$ & $\begin{array}{l}\text { RT: and weekly sessions, } 3 \text { sets of } 8-10 \\
\text { repetitions, with intensity progression } \\
\text { every } 2 \text { weeks, for } \sim 96 \text { weeks ( } 2 \text { years). }\end{array}$ & $\begin{array}{l}148 \text { Women between } \\
\text { 24-44 years }\end{array}$ & $\begin{array}{l}\text { No effect on BMD, only on } \\
\text { femoral neck BMC (+ } 1.5 \%) \\
\text { throughout the intervention. }\end{array}$ \\
\hline
\end{tabular}

* RM: maximum repetitions; **UL e LL = upper and lower limb.

\section{Evidence of the association between body composition and bone remodeling}

It is well established that indicators of body constitution, such as LM and FM (total or regional), are relevant factors in the prevention of disorders of bone metabolism, including pathologies such as osteoporosis. ${ }^{40-42}$ Admittedly, LM exerts a mechanical stimulus capable of favoring bone mineralization, while FM seems to exert an indirect influence by the modulation of hormones such as estrogen, leptin and insulin, which stimulate the deposition of minerals in the bone. ${ }^{43-45}$

Proctor et al. ${ }^{6}$ showed high and significant correlations between MM and BMC for males $(r=0.77)$ and females $(r=0.74)$. The study by Lee et al. ${ }^{1}$ corroborated this association, concluding that MM is a significant and independent determinant of total and regional bone mineral mass, presenting low coefficients $\left(r^{2}<0.5\right)$ but significant $(p<0.01)$ for associations between appendiculae mass $(\mathrm{kg})$ and total BMD, pelvic and forearm. These associations between body composition and bone mineral mass were also observed by Makovey et al. ${ }^{3}$ in populations of both sexes in different age groups. According to the results of these authors, both LM and FM positively influence BMC, with explanatory potential of 52\% for the variances between LM and BMC and of 20\% between FM and BMC. Among older women, non-obese, with and without osteoporosis, both LM and FM try to associate with BMD $\left(r^{2}=0.379, p<0.001\right)$ and BMC $\left(r^{2}=0.538, p<0.001\right)$ for the whole body, but FM becomes relevant when there is a low amount of LM in the body. ${ }^{42}$

In the study by Taaffe et al. ${ }^{38}$, involving elderly (70-79 years) of both sexes and different ethnicities, the LM was determinant for the BMD of femur, lower and upper limbs and whole body. These authors also observed that the association with (regional or whole-body) is potentially influenced by the region of body, sex and treatment of the variable, but not ethnicity. When analyzing, specifically, BMD of femur (region with function of sustaining the body), the authors report that total LM ( $r=$ $0.41)$, total FM ( $r=0.38)$, LM in the upper limbs $(r=0.35)$ and FM in the upper limbs $(r=0.36)$ are all influential factors $(p<0.001)$, but only the increase in LM promoted changes between 5.7\% and 5.9\% in femur $\mathrm{BMD}$, since the increase in FM affecting only femoral BMD (4.0-4.4\%).

Another important factor is the distribution pattern of $L M$. There are regional trends indicating the role of LM increase in the alterations of $\mathrm{BMC}$ at the same region, due to hormonal and mechanical stimulus delivered by greater muscle mass activity. ${ }^{46}$ However, this regionalization of the stimulus is more evident among men than women. In the study of Guimarães et al. ${ }^{47}$, involving young adult women, the total body LM variable showed higher associations ( $r \sim 0.55$ to 0.93 ) with total and regional BMC/BMD (i.e., lower and upper limbs, hip, and thoracic and lumbar vertebrae) than the upper limb LM ( $r \sim 0.57$ to 0.88) and lower limbs ( $r \sim 0.53$ to 0.87). Although the effect of regional variables on body composition was not analyzed by Chaves et al. ${ }^{48}$, the authors had already observed the potential of total body MM in determining variations in femoral colony BMD ( $r=0.44)$ among elderly women (6070 years), leading the authors to emphasize the benefit of musculature to postmenopausal bone tissue.

On the other hand, among men, Guimarães et al. ${ }^{49}$ observed a greater potential of regional LM in determining BMC/BMD of specific body sites. This potential highlights the importance of $L M$ of lower and upper limbs that show associations both to local (LM vs. BMC/BMD from the same region, with $r \sim 0.70$ to 0.86 ) and remote body regions ( $L M$ vs. BMC/BMD from different body regions, ranging from 0.60 to 0.83 ).

In addition, Xiang et al..$^{50}$ demonstrated that BMD for the whole-body, or specific regions such as the spine and hip, is positively influenced by physical activity and mediated by the variation of total LM and FM in the body, regardless of age and height, including the postmenopausal phase, when compared to those women with lower indexes of these parameters and in the same phases of life. These authors concluded, therefore, that LM is a mediator with effect between $19 \%$ and $48 \%$ on variations of BMD of the whole body and regions like spine and hip, in addition to being associated positively (0.112 to 0.759$)$ with physical activity. In relation to $M G$, these authors describe a negative effect ( -0.524 to -0.940 ) on BMD variations (22\% to 33\%), when mediated by the level of physical activity. Therefore, these authors suggest that postmenopausal women are at risk for the development of osteoporosis when they have low levels of physical activity.

\section{Evidence of the association between muscle strength and bone remodeling}

Strength and muscle mass have been considered as mechanical stimuli with a dominant effect on bone mass (BMC) or bone density 
(BMD) variations, and related to other non-mechanical stimuli (metabolic or hormonal), able to modulate not only bone metabolism and muscle, but also the responsiveness of bone tissue to mechanical stress, especially among young and adults of both sexes. ${ }^{16-19,41}$

For Matsui et al. ${ }^{51}$ the reduction of knee extensor strength is associated with femoral colon osteopenia between 763 males and 476 females, ranging in age from 40 to 81 years, in a 6-year longitudinal study. These authors also demonstrated that participants who already had osteopenia in the lumbar vertebrae developed osteoporosis with reduced strength of knee extensors, but the effect was significant only among men. Thus, the authors concluded that quadriceps strength should be developed to avoid the loss of local bone mass (by direct action of mechanical stress on the bone) or remote (by the systemic action of the physical activity on the bone metabolism).

Regarding the type of exercise, Guimarães et al. ${ }^{49}$ observed local and remote associations between maximal strength in multi-articular resistance exercises and BMD among men of university age ( $\sim 25$ years). According to these authors, the strength for large upper limb muscles (right and upper-right supine muscles) are not only good indicators of upper limb BMC/BMD ( $r \sim 0.57$ to 0.72), but also BMC/BMD of lower limbs and sites susceptible to osteoporosis such as bones of the hip region ( $r$ $\sim 0.36$ to 0.47 ). These authors also demonstrated that the strength for lower limb muscles (leg-press 450) also exhibits local effect (BMC/BMD of lower limb, $r \sim 0.42$ to 0.46 ) and remote (BMC/BMD upper limb and body , $r=0.35$ to 0.60 ), but with reduced potential relative to the upper limbs. Among females, maximal strength in mono and multi-articular exercises for lower limbs (i.e.: extensor chair and leg press 45) were better indicators associated to BMC/BMD, both for the region engaged in the exercise (local effect, $r=0.67$ to 0.78 ) and for others regions of the body, as well as, for whole body (remote effect, $r=0.53$ to 0.85 ), when compared to associations evidenced for maximal strength in upper limbs (ie: bench press), with local effect only, but not negligible ( $r=0.75$ to 0.84). ${ }^{47}$ In addition, the change in leg-press and knee extension muscle strength were associated to changes in femoral BMD ( $r=0.370 .46 p$ $<0.01$ ) for people of different ages and both sexes. ${ }^{52}$

\section{Effects of resistance training on body composition, muscle strength and bone remodeling}

Resistance training has recognized prescriptions able to modulate bone mineralization, which is recommend to be perform with high loads, two to three sets per exercise for three times a week for 4 to 12 months, with load intensity ranging from 50 to $80 \%$ of 1-RM, and engaging upper-limbs (MS) and lower-limbs (MI) to achieve an increase of BMD up to $3.8 \%$, or prevented significant reductions $(\sim 2.5 \%)$, when compared to non-exercise persons. ${ }^{11-14,22,53}$

A classic example of this potential for RT is the study of Nickols-Richardson et al. ${ }^{54}$, involving young women in unilateral, high-load training program for a period of 5 months, in which improvements in BMD were observed in different body regions for both trained and non-trained body segment, highlighting the changes of whole-body BMD $(+0.4 \%$ control and $+0.6 \%$ trained) and BMD in femur (0.5\% control and 1.2\% trained). However, it is not all the studies that show changes in BMC and BMD due to resistance exercise. For Chilibeck et al..$^{55}$, a 20-week RT for 30-year-old women was sufficient to increase muscle strength (by 70\%), LM (by 10\%), but BMC and BMD for whole-body and different body regions have not changed. Neither in the study by Fujimura et al. ${ }^{56}$ were changes found in BMC or BMD for whole-body or specific body regions after a 4-month RT program planned with loads between 60-80\% 1RM.

On the other hand, among premenopausal women (35-45 years), the study of Winter-Stone ${ }^{57}$ investigated an increase in femoral BMD in groups trained for 12 months with: (a) high-impact exercises for lower limbs, and (b) high-impact exercises for lower limbs combined with resisted upper limb exercise. Among postmenopausal women at risk of osteoporosis, there was an increase in body and femoral BMD after an 11-month training program involving impact (staircase: 60 to $85 \%$ maximal heart rate) and contractile tension stimulus (load intensity referring to 8 to $12-\mathrm{RMs})^{52}$. Among middle-aged men (54-61 years), Huuskonen et al..$^{58}$ observed an increase in femoral BMD in 3.8\%, after 4 months of resistance exercises planned with three weekly sessions and load between 5 and 15 RM.

The studies highlighted in Boards 1 and 2 provide updated results corroborating the effects of RT on bone remodeling. Studies that showed a greater effect of RT on BMC/BMD reported changes between 6 and $8 \% \%^{21,22,32}$. These studies encompassed a varied population as to age, sex and training protocols, using only resistance exercises, but with different loading intensities, with the exception of the Petersen et al. ${ }^{24}$ study, which included exercise for cardiovascular endurance on a bicycle. For Petersen et al. ${ }^{24}$, the use of low loads (20\% 1-RM) associated to the high number of repetitions showed similar effectiveness to other studies that employed intensity between 50-95\% 1-RM 21,32. Additionally, the study of Almstedt et al. ${ }^{32}$ which analyzed the alterations by sex, indicated that among men the effects were more pronounced. For these authors, this could be explained to the differences in hormonal response, initial muscle strength level and food intake in men than women, making the response of BMC/BMD different from the stimulus of RT.

Even, it cannot be state that the effects of RT on BMC/BMD would vary according to the type of exercises and amount of muscle mass engaged in exercise, since only the study of Huovinen et al. ${ }^{21}$ used multi-joint exercises exclusively. Meanwhile, the studies of Petersen et al. ${ }^{24}$ and Almstedt et al. ${ }^{32}$ included only small muscle exercises in the protocol, as well as exercises for pelvic region. Indeed, training programs planned with exercises for the different body parts tend to be effectiveness for general conditioning proposes, with no risk to constraints bone remodeling of specific sites such as hip and lumbar vertebrae, for those were recommended to approach the specificity from impacting exercises (jumps and variations) and exercises for lower limbs (such as squatting and ground lifting). ${ }^{29}$

Another part of studies inserted in Board 1 and 2 observed positive effects of 1 to $2 \%$ in average for the changes of BMC/BMD, as it be from isolated RT protocols, or combined with impact or cardiovascular endurance exercises using weight-bearing exercises (running, for example). In these studies can be also highlight the fact that RT applied to the population of different age groups and both sexes obtained a similar magnitude of effect on BMC/BMD, no matter the protocol duration (12 to 24 months) $)^{35}$, the frequency ( 2 vs. 3 weekly sessions), the load (80 vs. $40 \% 1-R M)^{31}$, the schedule of training progression to alter overload (linear vs. ondulatory) ${ }^{34}$, or even the variation of series ( 2 vs. 3 series $)^{20}$, and finally by the way to perform resistance exercise (circuit vs. traditional) ${ }^{30}$.

It is also noted that the combination of impact exercises with RT for a period between 8 and 12 months did not demonstrated to be more effective strategy than the isolated RT to change BMC/BMD. For Hinton et al. ${ }^{27}$ the changes in whole-body and regional BMD in middle-aged men after resistive and impact exercise training were different from baseline, but similar between groups, with the exception of hip BMD that altered most with the RT. However, for Liang et al. ${ }^{33}$, no changes were observed between trained groups (resistance and impact) with control group, involving young adult women. Perhaps, the absence of changes on whole-body and regional BMD in the study of Liang et al. ${ }^{33}$ can be explained by the planned volume of jumps, which may interfere with the percentage of BMD changes in the hip and femoral trochanter, as observed by Bolam et al. ${ }^{26}$ in a population of middle-aged and elderly 
men. Even because of the intensity of the load used in the RT, which requires loads between 80-85\% 1-RM for multi-joint exercises in upper and lower limbs to significantly change the BMD of the lumbar vertebrae and femoral neck, according to the study of Watson et al. ${ }^{22}$

In fact, when reviewing the results of BMD from studies including women in per- and post-menopausal period ( $~ 50-75$ years), planning interventions between 6 and 24 months and used impact exercises alone, or in combination to RT (example: 2-3 series, 6-8 repetitions at 70-80\% 1-RM, coupled with step exercises or jump on boxes) were observed positive increments between $1 \%$ and $2 \%$ for the lumbar region and femoral neck. ${ }^{53,59}$ However, it was emphasized that RT (example: 2 sets, 8 repetitions at $80 \%$ 1-RM, and 2 weekly sessions) did not present the same effectiveness when employed alone, but it was enough to avoid reductions (increase $\leq 1 \%$ trained group vs. reductions of up to $2.5 \%$ control group). ${ }^{53,59}$

However, the biological importance of these small changes, or even the unchanged of BMC/BMD values in response to RT can be understood by the fact that men and women up to 50 years of age have a BMC/ BMD decline rate of 0, 3 to $1.1 \%$ per year, which increases considerably among women after 50 years ${ }^{27,34}$. Furthermore, the majority of studies highlighted in Tables 1 and 2 show moderate ( 10\%) to high (> 80\%) changes of muscle strength in association to the low changes ( 2 to $5 \%$ ) in lean mass, being that sure for groups of elderly people of both sexes ${ }^{7}$, just elderly men ${ }^{25}$ or women ${ }^{21,30}$, groups of people with different ages and $\operatorname{sex}^{24}$, for young adults ${ }^{29}$ and children ${ }^{28}$. Such changes, together with cardiovascular conditioning, are negatively associated with mortality from different causes, as the risk of falls and fractures among elderly. 7,10,23,60

\section{CONCLUSION}

Collectively, the studies corroborated the integration between the patterns of changes of LM and muscle strength with BMC/BMD modulation. However, there are specific tendencies between men and women regarding bone growth up to adult life, as well as to the reduction of muscle and bone mass with aging. Regarding the mode of exercise to promote such integrated development, studies indicating the RT engaging multi-articular motions with high load intensity, as the preponderant stimulus promoting bone remodeling directly, or otherwise indirectly by the increase of regional or whole-body lean mass, regardless of age, sex and ethnicity. The specific guideline for RT approach 70-90\% 1RM, 2-3 sets per exercise, 1-3 minutes interval, 2-3 sessions per week for a period of 4 to 12 months, combining with impact exercises (such as a jump, if possible) to improve regional and whole-body BMC/BMD, as well as, for the prevention of osteoporosis after the 4 th or 5 th decades of life.

All authors declare no potential conflict of interest related to this article

AUTHORS' CONTRIBUTIONS: Each author made significant individual contributions to this manuscript. DMPF (0000-0003-3975-9260)*, LDP (0000-0001-7956-894X)*, DAM (00000003-1088-0040)*, DS (0000-0002-5565-2351)*, and CMN (0000-0003-1635-3209)* were responsible for the conception of the proposal, data collection, presentation of the results and literary discussion of the results observed. CMTV (0000-0003-2911-8339)*, ARS (0000-0003-0653-5383)*, LAT (0000-0001-9964-0654)* and BRG (0000-0003-3058-998X)* accompanied the data analysis, and contributed to the revision of the manuscript and conceptual basis of the study, and to the final conceptual review. All the authors approved the final version of the manuscript. *ORCID (Open Researcher and Contributor ID).

\section{REFERENCES}

1. Lee N, Radford-Smith GL, Forwood M, Wong J, Taaffe DR. Body composition and muscle strength as predictors of bone mineral density in Crohn's disease. J Bone Miner Metab. 2009;27(4):456-63.

2. Medical Advisory Secretariat. Utilization of DXA bone mineral densitometry in Ontario: an evidence-based analysis. Ont Heath Technol Assess Ser. 2006;6(20):1-180

3. Makovey J, Naganathan V, Sambrook P. Gender differences in relationships between body composition components, their distribution and bone mineral density: a cross-sectional opposite sex twin study. Osteoporos Int. 2005;16(12);1495-505.

4. Marques EA, Gudnason V, Sigurdsson G, Lang T, Johannesdottir F, Siggeirsdottir K, et al. Are bone turnover markers associated with volumetric bone density, size, and strength in older men and women? The AGES-Reykjavik study. Osteoporos Int. 2016;27(5):1765-76.

5. Gómez-Cabello A, Ara I, González-Agüero A, Casajús JA, Vicente-Rodriguez G. Effects of training on bone mass in older adults: a systematic review. Sports Med. 2012;42(4):301-25.

6. Proctor DN, Melton $\sqcup$, Khosla S, Crowson CS, O'Connor MK, Riggs B L. Relative influence of physical activity, muscle mass and strength on bone density. Osteoporos Int. 2000;11(11):944-52.

7. Villareal DT, Aguirre L, Gurney AB, Waters DL, Sinacore DR, Colombo E, et al. Aerobic or resistance exercise, or both, in dieting obese older adults. N Engl J Med. 2017;376(20):1943-55.

8. Chien MY,Wu YT, Hsu AT, Yang RS, Lai JS. Efficacy of a 24-week aerobic exercise program for osteopenic postmenopausal women. Calcifi Tissue Int. 2000;67(6):443-8.

9. Martin D, Notelovitz M. Effects of aerobic training on bone mineral density of postmenopausal women. J Bone Miner Res. 1993;8(8):931-6.

10. Marques EA, Wanderley F, Machado L, Sousa F, Viana JL, Moreira-Gonçalves D, et al. Effects of resistance and aerobic exercise on physical function, bone mineral density, OPG and RANKL in older women. Exp Gerontol. 2011;46(7):524-32.

11. Nelson ME, Fiatarone MA, Morganti CM, Trice I, Greenberg RA, Evans WJ. Effects of high-intensity strength training on multiple risk factors for osteoporotic fractures: a randomized controlled trial. JAMA. 1994;272(24):1909-14.

12. Bocalini DS, Serra AJ, dos Santos L, Murad N, Levy RF. Strength training preserves the bone mineral density of postmenopausal women without hormone replacement therapy. J Aging Health. 2009;21(3):519-27.

13. de Matos O, Lopes da Silva DJ, Martinez de Oliveira J, Castelo-Branco C. Effect of specific exercise training on bone mineral density in women with postmenopausal osteopenia or osteoporosis. Gynecol Endocrinol. 2009;25(9):616-20

14. Menkes A, Mazel S, Redmond RA, Koffler K, Libanati CR, Gundberg CM, et al. Strength training increases regional bone mineral density and bone remodeling in middle-aged and older men. J Appl Physiol (1985). 1993;74(5):2478-84

15. Frost HM. Muscle, bone, and the Utah paradigm: a 1999 overview. Med Sci Sports Exerc.. 2000;32(5):911-7
16. Burr DB. Muscle strength, bone mass, and age-related bone loss. J Bone Miner Res. 1997;12(10):1547-51 17. Schoenau E. From mechanostat theory to development of the "Functional Muscle-Bone-Unit". J Musculoskelet Neuronal Interact. 2005;5(3):232-8

18. Lang TF. The bone-muscle relationship in men and women. J Osteoporos. 2011;2011:70235.

19. Slemenda C, Longcope C, Peacock M, Hui S, Johnston CC. Sex steroids, bone mass, and bone loss. A prospective study of pre-, peri-, and postmenopausal women. J Clinl Invest. 1996;97(1):14-21.

20. Cunha PM, Ribeiro AS, Tomeleri CM, Schoenfeld BJ, Silva AM, Souza MF, et al. The effects of resistance training volume on osteosarcopenic obesity in older women. J Sports Sci. 2018;36(14):1564-71.

21. Huovinen V, Ivaska KK, Kiviranta R, Bucci M, Lipponen H, Sandboge S, et al. Bone mineral density is increased after a 16-week resistance training intervention in elderly women with decreased muscle strength. Eur J Endocrinol, 2016;175(6):571-82.

22. Watson SL, Weeks BK, Weis $L$, Horan SA, Beck BR. Heavy resistance training is safe and improves bone, function, and stature in postmenopausal women with low to very low bone mass: novel early findings from the LIFTMOR trial. Osteoporos Int. 2015;26(12):2889-94.

23. Beaver, KM, Beavers DP, Martin SB, Marsh AP, Lyles MF, Lenchik L, et al. Change in bone mineral density during weight loss with resistance versus aerobic exercise training in older adults. J Gerontol A Biol Sci Med Sci. 2017;72(11):1582-85.

24. Petersen BA, Hastings B, Gottschall JS. Low load, high repetition resistance training program increases bone mineral density in untrained adults. J Sports Med Phys Fitness. 2017;57(1-2):70-6.

25. Stunes AK, Syversen U, Berntsen S, Paulsen G, Stea TH, Hetlelid KJ, et al. High doses of vitamin C plus E reduce strength training-induced improvements in areal bone mineral density in elderly men. Eur J Appl Physiol. 2017;117(6):1073-84

26. Bolam KA, Skinner TL, Jenkins DG, Galvão DA, Taaffe DR. The osteogenic effect of impact-loading and resistance exercise on bone mineral density in middle-aged and older men: a pilot study. Gerontology. 2015;62(1):22-32

27. Hinton PS, Nigh P, Thyfault J. Effectiveness of resistance training or jumping-exercise to increase bone mineral density in men with low bone mass: A 12-month randomized, clinical trial. Bone. 2015;79:203-12

28. Cunha GS, Sant'anna MM, Cadore EL, Oliveira NL, Santos CB, Pinto RS, et al. Physiological adaptations to resistance training in prepubertal boys. Res Q Exerc Sport. 2015;86(2):172-81.

29. Mosti MP, Carlsen T, Aas E, Hoff J, Stunes AK, Syversen U. Maximal strength training improves bone mineral density and neuromuscular performance in young adult women. J Strength Cond Res. 2014;28(10):2935-45.

30. Romero-Arenas S, Blazevich AJ, Martínez-Pascual M, Pérez-Gómez J, Luque AJ, López-Román FJ, et al. Effects of high-resistance circuit training in an elderly population. Exp Gerontol. 2013;48(3):334-40.

31. Bemben DA, Bemben MG. Dose-response effect of 40 weeks of resistance training on bone mineral density in older adults. Osteoporos Int. 2011;22(1):179-86. 
32. Almstedt HC, Canepa JA, Ramirez DA, Shoepe TC. Changes in bone mineral density in response to 24 weeks of resistance training in college-age men and women. J Strength Cond Res. 2011;25(4):1098-103.

33. Liang MTC, Braun W, Bassin SL, Dutto D, Pontello A, Wong ND, et al. Effect of high-impact aerobics and strength training on BMD in young women aged 20-35 years. Int J Sports Med. 2011;32(02):100-8.

34. Vanni AC, Meyer F, Da Veiga AD, Zanardo VP. Comparison of the effects of two resistance training regimens on muscular and bone responses in premenopausal women. Osteoporos Int. 2010;21(9),1537-44.

35. Warren M, Petit MA, Hannan PJ, Schmitz KH. Strength training effects on bone mineral content and density in premenopausal women. Med Sci Sports Exerc. 2008;40(7):1282-8.

36. Slemenda C, Longcope C, Peacock M, Hui S, Johnston CC. Sex steroids, bone mass, and bone loss. A prospective study of pre-, peri-, and postmenopausal women. J Clinical Investigation. 1996;97(1):14-21.

37. Horber FF, Gruber B, Thomi F, Jensen EX, Jaeger P. Effect of sex and age on bone mass, body composition and fuel metabolism in humans. Nutrition. 1997;13(6):524-34

38. Taaffe DR, Cauley JA, Danielson M, Nevitt MC, Lang TF, Bauer DC, et al. Race and sex effects on the association between muscle strength, soft tissue, and bone mineral density in healthy elders: the health, aging, and body composition study. J Bone Miner Res. 2001;16(7):1343-52.

39. Young D, Hopper JL, Macinnis RJ, Nowson CA, Hoang NH, Wark JD. Changes in body composition as determinants of longitudinal changes in bone mineral measures in 8 to 26-year-old female twins. Osteoporos Int. 2001;12(6):506-15.

40. Chen Z, Lohman TG, Stini WA, Ritenbaugh C, Aickin M. Fat or lean tissue mass: which one is the major determinant of bone mineral mass in healthy postmenopausal women? J Bone Miner Res. 1997;12(1):144-51.

41. Reid IR. Relationships among body mass, its components, and bone. Bone. 2002;31 (5):547-55.

42. Gnudi S, Sitta E, Fiumi N. Relationship between body composition and bone mineral density in women with and without osteoporosis: relative contribution of lean and fat mass. J Bone Miner Metabol. 2007;25(5):326-32.

43. Beck TJ, Oreskovic TL, Stone KL, Ruff CB, Ensrud K, Nevitt MC, et al. Structural adaptation to changing skeletal load in the progression toward hip fragility: the study of osteoporotic fractures. J Bone Miner Res. 2001;16(6):1108-19.

44. Thomas T, Burguera B, Melton $L$ 3rd, Atkinson EJ, O'Fallon WM, Riggs BL, et al. Role of serum leptin, insulin, and estrogen levels as potential mediators of the relationship between fat mass and bone mineral density in men versus women. Bone. 2001;29(2):114-20.

45. Migliaccio S, Greco EA, Wannenes F, Donini LM, Lenzi A. Adipose, bone and muscle tissues as new endocrine organs: role of reciprocal regulation for osteoporosis and obesity development. Horm Mol Biol Clin Investig. 2014;17(1):39-51.

46. Matsuo T, Douchi T, Nakae M, Uto H, Oki T, Nagata Y. Relationship of upper body fat distribution to higher regional lean mass and bone mineral density. J Bone Miner Metab. 2003;21(3):179-83.
47. Guimarães BR, Pimenta LD, Massini DA, Santos DD, Siqueira LODC, Simionato AR. et al. Muscular strength and regional lean mass influence bone mineral health among young females. Rev Bras Med Esporte. 2018;24(3):186-91.

48. Chaves LM, Gomes L, Oliveira RJ, Marques MB. Relação entre variáveis da composição corporal e densidade mineral óssea em mulheres idosas. Rev Bras Med Esporte. 2005;11(6):352-6.

49. Guimarães BR, Pimenta LD, Massini DA, Dos Santos D, Siqueira LODC, Simionato AR, et al. Muscle strength and regional lean body mass influence on mineral bone health in young male adults. PloS One. 2018;13(1):e0191769.

50. Xiang J, Chen Y, Wang Y, Su S, Wang X, Xie B, et al. Lean mass and fat mass as mediators of the relationship between physical activity and bone mineral density in postmenopausal women. $J$ Womens Health (Larchmt). 2017;26(5):461-6.

51. Matsui Y, Takemura M, Harada A, Ando F, Shimokata H. Effects of knee extensor muscle strength on the incidence of osteopenia and osteoporosis after 6 years. J Bone Miner Metabol. 2014;32(5):550-5.

52. Ryan AS, Ivey FM, Hurlbut DE, Martel GF, Lemmer JT, Sorkin JD, et al. Regional bone mineral density after resistive training in young and older men and women. Scand J Med Sci Sports. 2004;14(1):16-23.

53. Zhao $\mathrm{R}$, Zhao $\mathrm{M}$, Xu Z. The effects of differing resistance training modes on the preservation of bone mineral density in postmenopausal women: a meta-analysis. Osteoporos Int. 2015;26(5):1605-18.

54. Nickols-Richardson SM, Miller LE, Wootten DF, Ramp WK, Herbert WG. Concentric and eccentric isokinetic resistance training similarly increases muscular strength, fat-free soft tissue mass, and specific bone mineral measurements in young women. Osteoporos Int. 2007;18(6):789-96.

55. Chilibeck PD, Calder A, Sale DG, Webber CE. Twenty weeks of weight training increases lean tissue mass but not bone mineral mass or density in healthy, active young women. Can J Physiol Pharmacol. 1996;74(10):1180-5.

56. Fujimura R, Ashizawa N, Watanabe M, Mukai N, Amagai H, Fukubayashi T, et al. Effect of resistance exercise training on bone formation and resorption in young male subjects assessed by biomarkers of bone metabolism. J Bone Miner Res. 1997;12(4):656-62.

57. Winters-Stone KM, Snow CM. Site-specific response of bone to exercise in premenopausal women Bone. 2006;39(6):1203-9.

58. Huuskonen J, Väisänen SB, Kröger H, Jurvelin JS, Alhava E, Rauramaa R. Regular physical exercise and bone mineral density: a four-year controlled randomized trial in middle-aged men. The DNASCO study Osteoporos Int. 2001;12(5):349-55.

59. Sañudo B, de Hoyo M, Del Pozo-Cruz J, Carrasco L, Del Pozo-Cruz B, Tejero S, et al. A systematic review of the exercise effect on bone health: the importance of assessing mechanical loading in perimenopausal and postmenopausal women. Menopause. 2017;24(10):1208-16.

60. Guadalupe-Grau A, Fuentes T, Guerra B, Calbet JA. Exercise and bone mass in adults. Sports Med. 2009;39(6):439-68. 